\title{
SOIL DEVELOPMENT ON LOESS OVERLYING CRETACEOUS SEDIMENTS AND DEVONIAN LIMESTONES
}

\author{
Anna ŽIGOVÁ * and Martin ŠŤASTNÝ \\ Institute of Geology of the CAS, v. v. i., Rozvojová 269, 16500 Prague 6-Lysolaje, Czech Republic \\ *Corresponding author's e-mail: zigova@gli.cas.cz
}

\begin{tabular}{l} 
ARTICLE INFO \\
\hline Article history: \\
Received 2 February 2015 \\
Accepted 13 May 2015 \\
Available online 13 July 2015 \\
\hline
\end{tabular}

Keywords:

Loess

Cretaceous and Devonian rocks

Mineral composition

Soil development

Luvic Chernozem

Albic Luvisol

\begin{abstract}
The development of soil cover on loess in regions of Cretaceous sediments and Devonian limestones in the Bohemian Massif was analysed. The study was performed in areas with different land use. Parent material was characterized on the basis of thin section study. Soils were evaluated by macromorphological analysis, particle size distribution, chemical properties, parameters of soil organic matter and mineral composition of clay fraction. The results revealed differences in the formation of soil cover which are predominately connected with geological conditions. The main pedogenetic process for Bohemian Cretaceous Basin is humification. Pedogenetic clay differentiation is relatively slight. Intense pedogenetic clay differentiation, less pronounced processes of litter formation and humification are characteristic for soils in the Devonian limestone areas. The intensity of processes of pedogenetic clay differentiation is influenced by $\mathrm{pH}$ values. The quality and quantity of soil organic matter were influenced by the source of biomass, biological activity and type of land use. Petrography of parent material from thin sections shows some differences among features of $\mathrm{Ck}$ horizons. The most abundant minerals of clay fraction of the studied soil are quartz, illite and kaolinite. Bt horizons of Albic Luvisols have an elevated content of illite.
\end{abstract}

\section{INTRODUCTION}

Soils formed on loess are commonly found in different regions. The concept mapping loess distribution in Western, Central and Eastern Europe was published by Haase et al. (2007). The origin of various type of loess was subject of works by Pécsi (1990) and Nemecz et al. (2000). The study of loess in the Czech Republic usually involves data about the mode of occurrence, significant fauna and regional characteristics. Such information can be found in the studies of Kukla and Ložek (1961), Tomášek (1998), Frechen et al. (1999) and Cilek (2001).

Data about pedogenesis on loess in the territory of Czech Republic are scattered, predominantly focused on the genesis of fossil soil types (Smolíková 1972, 1984). Some aspects of Recent soils were described by Němeček (1981). The mineral composition of loess-paleosol sequences in different regions was characterized for example by Hradilová and Št’astný (1994), Št’astný (1997), Perederij (2001), Bronger (2003), Dodonov et al. (2006) and Huang et al. (2014). On the other hand, studies concerning soil development and mineral composition of Recent soils developed on loess are rather rare (Sirový, 1964; Śály and Mihálik, 1970). The relationships among soil organic matter, soil chemical properties and soil mineral composition in young soils developed on loess are not very often a subject to investigation. Few studies describing modern pedogenesis on loess can be found from the territory of Iran (Khormali and
Ajami, 2011; Khormali et al., 2012), Kansas (Gunal and Ransom, 2006) and Russia (Sokolova et al., 2010).

The development of Recent soil on loess in the conditions of the Czech Republic may differ depending on local geological basement. The objective of this study is to compare the types of pedogenesis of the Bohemian Cretaceous Basin and in Devonian limestones of the Prague Basin and Moravian Karst, and to characterize the basic properties and mineral composition of soils.

\section{MATERIAL AND METHODS}

The present research was conducted in agricultural landscapes with wheat fields and national nature reserves with oak-hornbeam forests. The positions of individual sites are presented in Figure 1. The locations of soil profiles were measured using GARMIN eTrex Summit in the WGS 84 system. Typical sequences were selected on the basis of soil survey. Characteristic soil profiles were excavated down to the parent material. Field description of morphology of the studied soil profiles was done according to Jahn et al. (2006). Soils were classified according to the IUSS Working Group WRB (2014). Samples were collected from all soil pits, except O horizons. Soil profiles were situated in the plains (Luvic Chernozems) and in mid parts of gentle slopes (Albic Luvisols). 


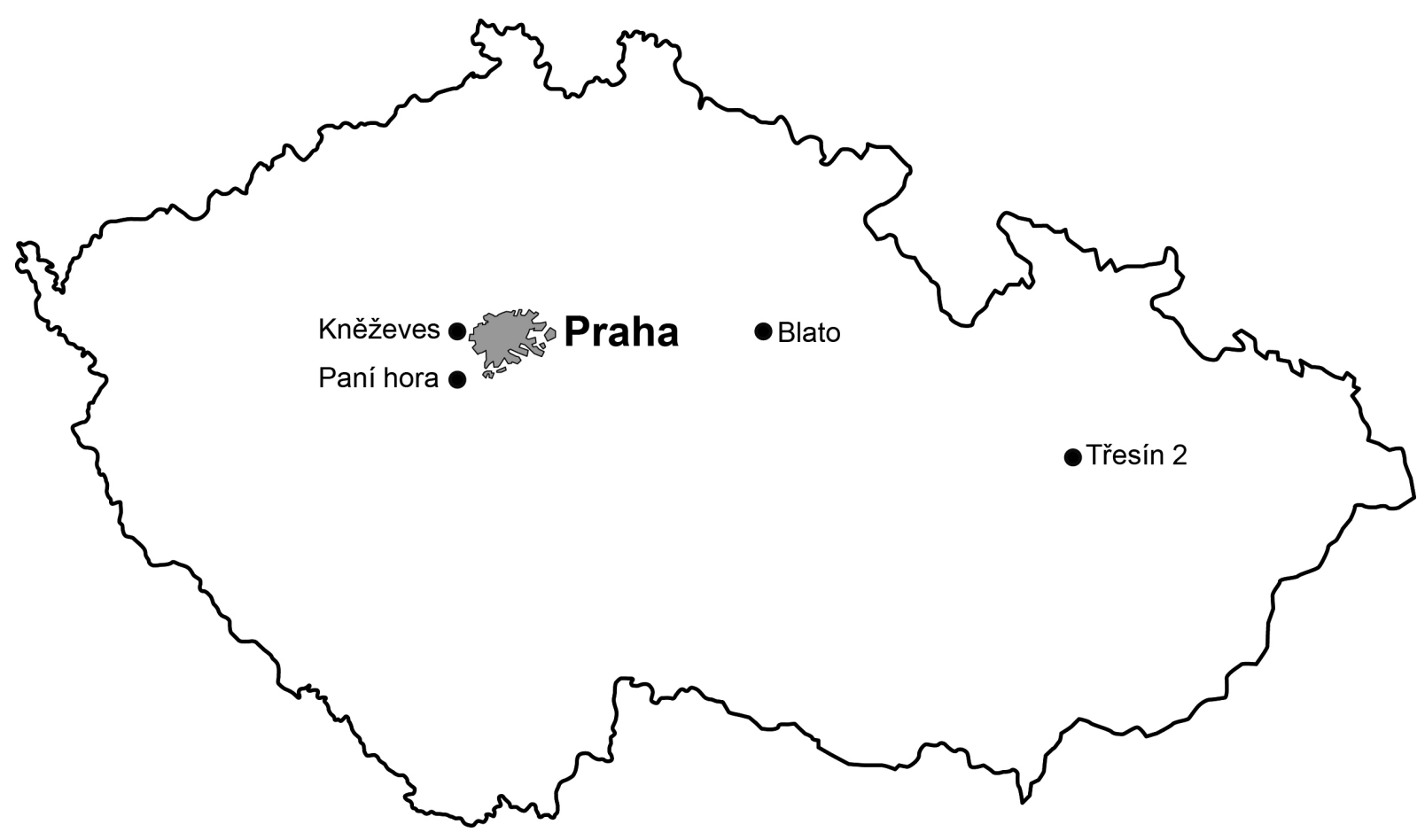

Fig. 1 Location of soil profiles.

The climate was characterized by Quitt (1971). The studied sites are situated in the warm climatic region T 2 (160-170 days with mean temperature of $10{ }^{\circ} \mathrm{C}, 90-100$ days with precipitations $\geq 1 \mathrm{~mm}$ and 40-50 days with snow cover).

Blato and Kněževes are located in the Elbe and Vltava-Beroun regions of the Bohemian Cretaceous Basin (Mísař et al., 1983).

The Blato site is located $100 \mathrm{~km}$ to the east of Prague. Loess overlies Cretaceous sediments which are predominately composed of marlstone of Turonian age. Holásek et al. (1989) described outcrops of Cretaceous sediments on the surface of the surrounding ridges, for example marlstone of Middle Turonian age (Jizera Formation) to the east of the study area. Approximately $2 \mathrm{~km}$ to the northeast of this site, calcareous claystones of Upper Turonian age (Teplice Formation) emerge from the gravel- and sand-dominated Elbe River floodplain.

The site of Kněževes lies $10 \mathrm{~km}$ to the west of Prague. Loess overlies different types of Cenomanian sandstones (Korycany and Peruc members) and also Turonian sandy marlstone (Bílá hora Formation; Vejlupek, 1988). Approximately $2.5 \mathrm{~km}$ to the northwest of the study area, a ridge of Proterozoic lydite is surrounded by Cenomanian sediments.

Paní hora and Třesín 2 are located in areas dominated by limestones of Devonian age in various karst regions (Mísař et al., 1983).

The site of Paní hora is situated in the Bohemian Karst (Karlštejn National Nature Reserve) $25 \mathrm{~km}$ to the southwest of Prague. In this case loess occurs in the central part of the Prague Basin, comprising the
Ordovician bedrock and then Silurian-Devonian formations. Different types of limestones of Lower Devonian (Lochkovian, Pragian and Emsian stages) and Middle Devonian age (Eifelian stage) alternate in several anticline zones (Chlupáč, 1974). The Upper Devonian sediments are dominated by clay and sand, mostly represented by dark shales, calcareous siltstones and sandstones.

The area of Třesín 2 is located in the Mladeč Karst (Třesín National Nature Reserve) $232 \mathrm{~km}$ to the southeast of Prague. This site lies at the eastern foot of the Třesín Hill, where limestone is a part of the Konice-Mladeč Devonian. This creates a triangular structure in the direction SW-NE, which start to the west of Konice and ends at Mladeč in the SE. The occurrence of Devonian rocks is terminated by the Konice-Nectavy Fault in the SW and then by the Kladecko-Kadeřín Fault. The area is divided by faults into a number of transverse blocks and several longitudinal blocks (Crha, 1979). Devonian rocks are surrounded by Lower Carboniferous rocks of the Culm facies (Chlupáč and Svoboda, 1963). Devonian limestones overlie shale in the individual islands. These are mainly limestones of the Lažánky, Vilémovice and Němčice types. These light grey finegrained limestones pass upwards to grey and dark grey, weakly metamorphosed and tectonized limestone.

All laboratory analyses of soil characteristics followed standard methods (Valla et al., 2002). Particle size distribution was determined using the pipette method. Soil $\mathrm{pH}$ in $\mathrm{H}_{2} \mathrm{O}$ and in $1 \mathrm{M} \mathrm{KCl}$ was measured in the suspension of a soil:liquid mixture in 
a ratiol:2.5. Determination of carbonate content was done by volumetric method using $10 \% \mathrm{HCl}$. Cation exchange capacity was done using the method of Mehlich. Organic carbon was determined by wet combustion with a mixture of potassium dichromate and sulphuric acid at about $125{ }^{\circ} \mathrm{C}$. The residual dichromate was titrated against ferrous sulphate. Total nitrogen was determined using the Kjedahl method. Thin sections of parent material were examined with the OLYMPUS BX51 polarizing microscope with the DP70 digital camera. Clay fraction of soils was prepared for X-ray diffraction analyses. Prior to the Xray diffraction of samples, organic matter was removed using $30 \% \mathrm{H}_{2} \mathrm{O}_{2}$. Carbonates were removed by $0.1 \mathrm{~N}$ monochloroacetic acid. The specimens were then washed with distilled water. Clay fraction was obtained using a sedimentation method. Oriented samples were prepared by pipetting the suspension and deposited on a glass slide and allowing it to dry at ambient temperature. Specimens were analysed in natural state, then saturated for four hours in ethyleneglycol at $80{ }^{\circ} \mathrm{C}$ and heated at $550{ }^{\circ} \mathrm{C}$ for 4 hours. XRD spectra were obtained on the PW3020 Philips X'Pert diffractometer with $\mathrm{CoK} \alpha$ radiation (Blato and Kněževes) and $\mathrm{CuK} \alpha$ radiation (Paní hora and Třesín). X-ray patterns were recorded at a goniometric shift of $1^{\circ} \cdot \mathrm{min}^{-1} .2 \Theta$. Semiquantitave values were calculated based on the height of individual mineral basal peaks using correction coefficients (Melka, personal communication, 2013).

\section{RESULTS AND DISCUSSION}

\section{BASIC MORPHOLOGICAL CHARACTERISTIC OF SOIL PROFILES}

Examination and description of soil profiles in the field were performed to provide reliable information on the morphology of soil profiles. Data about coordinates $\mathrm{N}$ and $\mathrm{E}$, altitude and succession of horizons are given in Table 1.

The soil profiles of Blato (Figure 2) and Kněževes (Figure 3) were classified as Luvic Chernozems. These sequences have various thicknesses of diagnostic horizons and various intensities of expression of typical features. Human impact on the Ap horizon is more significant at the Kněževes site than at the Blato site. Biological activity in the Ah horizon and common greyish brown coatings in the Bth horizons are more significant at the Blato site than in the Knězeves area The $\mathrm{Ck}$ horizon started at $117 \mathrm{~cm}$ in the Blato profile and at $85 \mathrm{~cm}$ in the Kněževes pit. Pseudomycelias in this horizon were described from both sites. Soft carbonate concretions are present in the Kněževes profile, and hard carbonate concretions are also present in the pit of Blato.

The studied sequences of Paní hora (Figure 4) and Třesín 2 (Figure 5) were classified as Albic Luvisol. The thickness of the $\mathrm{O}$ horizon is $2 \mathrm{~cm}$ and the thicknesses of the $\mathrm{Ah}$ horizons are $4 \mathrm{~cm}$. Biological activity is relatively weak. These profiles have $\mathrm{E}$ horizons. The presence of brown clay coatings is common in the $\mathrm{Bt}$ horizons. The $\mathrm{Ck}$ horizon started at $122 \mathrm{~cm}$ in the Paní hora profile and at $191 \mathrm{~cm}$ in the Třesín 2 pit. The occurrence of pseudomycelias and soft carbonate concretions are more significant at the Třesín 2 site than in the Paní hora profile.

Morphological analysis of profiles shows differences in soil development on loess. Processes of disturbance by human activity, such as mixing of the upper soil profile by ploughing, humification and relatively slight pedogenetic clay differentiation, are characteristic for the studied Luvic Chernozem of the Bohemian Cretaceous Basin. Litter formation, humification and intense pedogenetic clay differentiation were identified for Albic Luvisols in national nature reserves with Devonian limestone.

\section{PARTICLE SIZE DISTRIBUTION}

The results of particle size analysis and texture class of the soil profiles are shown in Table 2. Silt fraction dominates at all sites which is characteristic for soils developed on loess. The amount of sand fraction is probably influenced by local geological conditions. Elevated portion of clay fraction in the $\mathrm{Bt}$ and Bth horizons indicates the process of pedogenetic clay differentiation. Albic Luvisol (Paní hora and Třesín) has a higher degree of texture differentiation by clay particles than Luvic Chernozem (Blato and Kněževes). This method allowed to qualitatively confirm the process of pedogenetic clay differentiation which was documented by macromorphological description of soil during field works.

Table 1 Basic information about the studied profiles.

\begin{tabular}{lllll}
\hline Profile & Coordinate N & Coordinate E & Elevation & Stratigraphy of soil profile \\
\hline Blato & $49^{\circ} 59^{\prime}$ & $15^{\circ} 46^{\prime}$ & $244 \mathrm{~m}$ a.s.l. & Ap-Ah-Bth1-Bth2-Ck \\
Kněževes & $50^{\circ} 07^{\prime}$ & $14^{\circ} 17^{\prime}$ & $348 \mathrm{~m}$ a.s.l. & Ap-Ah-Bth-Ck \\
Paní hora & $49^{\circ} 57^{\prime}$ & $14^{\circ} 09^{\prime}$ & $285 \mathrm{~m}$ a.s.l. & O-Ah-AhE-E-EBt1-Bt1-Bt2-Ck \\
Třesín 2 & $49^{\circ} 42^{\prime}$ & $17^{\circ} 01^{\prime}$ & $239 \mathrm{~m}$ a.s.l. & O-Ah-E-EBt1-Bt1-Bt2-Ck \\
\hline
\end{tabular}




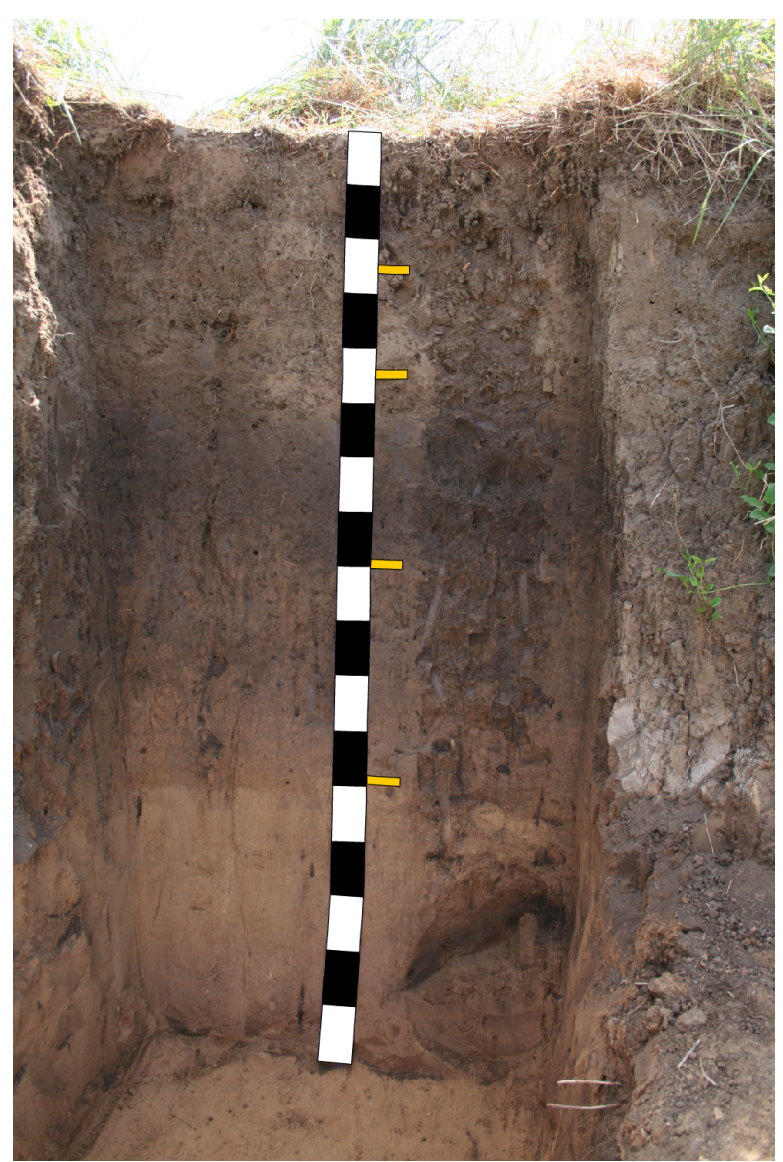

Fig. 2 Soil profile from the Blato site, each step on the scale bar corresponds to $10 \mathrm{~cm}$ (photo A. Žigová).

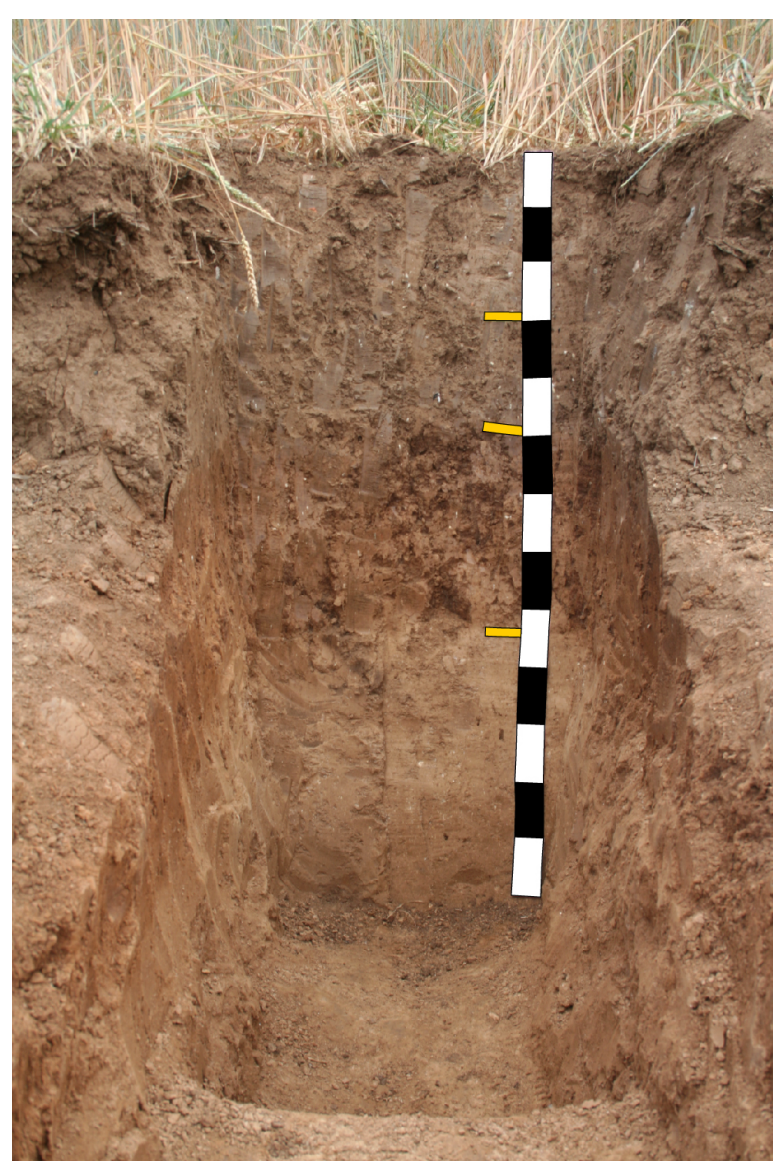

Fig. 3 Soil profile from the Kněževes site, each step on the scale bar corresponds to $10 \mathrm{~cm}$ (photo A. Žigová).

Table 2 Particle size distribution (\%).

\begin{tabular}{lcccrl}
\hline Profile & $\begin{array}{c}\text { Depth } \\
\mathrm{cm}\end{array}$ & $\begin{array}{c}\text { Clay } \\
<0.002 \mathrm{~mm}\end{array}$ & $\begin{array}{c}\text { Silt } \\
0.002-0.05 \mathrm{~mm}\end{array}$ & $\begin{array}{c}\text { Sand } \\
0.05-2.00 \mathrm{~mm}\end{array}$ & Texture class \\
\hline Blato & $0-24$ & 13.5 & 61.9 & 24.6 & silt loam \\
& $24-43$ & 16.7 & 55.1 & 28.2 & silt loam \\
& $43-78$ & 23.4 & 54.3 & 22.3 & silt loam \\
& $78-117$ & 25.7 & 46.0 & 28.3 & loam \\
& $117-170$ & 17.1 & 57.9 & 25.0 & silt loam \\
\hline Kněževes & $0-30$ & 28,6 & 64.4 & 7.0 & silty clay loam \\
& $30-48$ & 24.0 & 71.6 & 4.4 & silt loam \\
& $48-85$ & 33.0 & 63.0 & 4.0 & silty clay loam \\
& $85-130$ & 26.1 & 69.3 & 4.6 & silty loam \\
\hline Paní hora & $0-4$ & 14.6 & 41.5 & 43.9 & loam \\
& $4-11$ & 19.7 & 52.3 & 28.0 & silt loam \\
& $11-25$ & 20.4 & 53.2 & 26.4 & silt loam \\
& $25-38$ & 28.9 & 58.4 & 12.7 & silty clay loam \\
& $38-62$ & 38.1 & 52.0 & 9.9 & silty clay loam \\
& $62-122$ & 29.9 & 50.0 & 20.1 & clay loam \\
& $122-209$ & 16.0 & 61.6 & 22.4 & silt loam \\
\hline Třesín 2 & $0-4$ & 9.1 & 73.9 & 17.0 & silt loam \\
& $4-43$ & 12.0 & 74.5 & 13.5 & silt loam \\
& $43-65$ & 14.0 & 74.0 & 12.0 & silt loam \\
& $65-117$ & 22.0 & 63.0 & 15.0 & silt loam \\
& $117-191$ & 23.1 & 66.1 & 10.8 & silt loam \\
& $191-221$ & 13.4 & 73.5 & 13.1 & silt loam \\
\hline
\end{tabular}




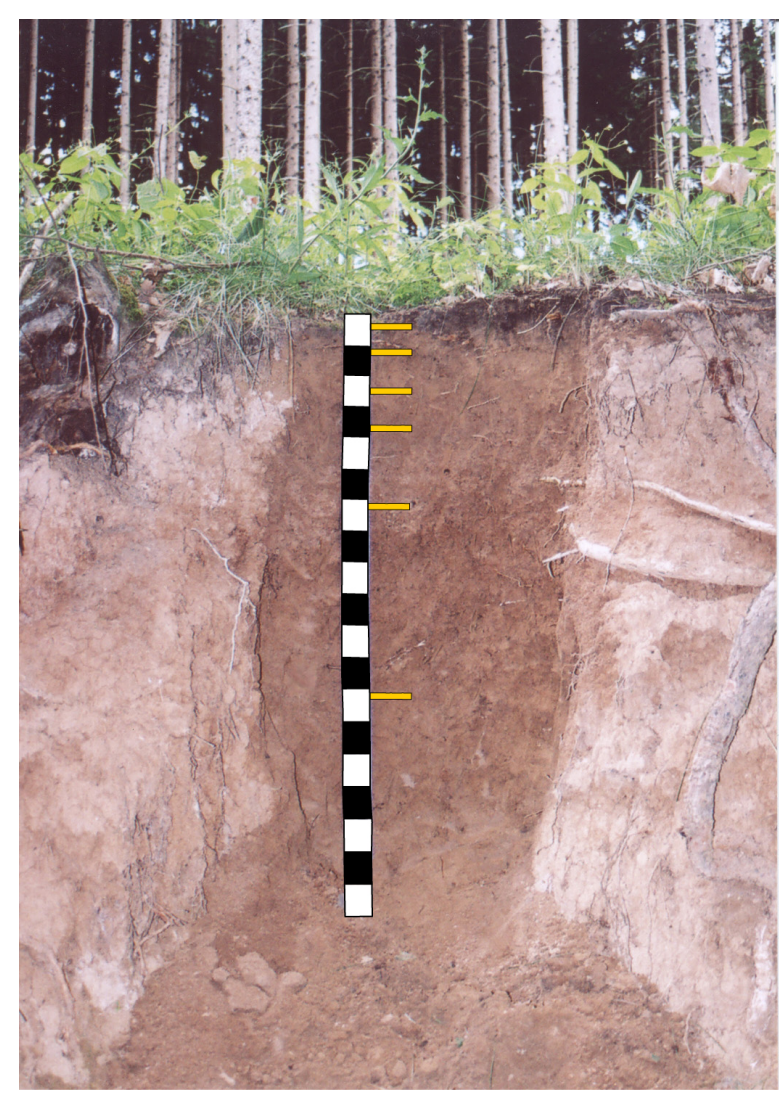

Fig. 4 Soil profile from the Paní hora site, each step on the scale bar corresponds to $10 \mathrm{~cm}$ (photo A. Žigová).

\section{CHEMICAL PROPERTIES}

These data are summarized in Table 3. The $\mathrm{pH}$ values were assessed by the scale of Baize (1993). Luvic Chernozem (Blato and Kněževes) has a neutral reaction and a basic one in horizon $\mathrm{Ck}$. Albic Luvisol from the Paní hora site shows mostly very acid $\mathrm{pH}$ and basic $\mathrm{pH}$ in the $\mathrm{Ck}$ horizon. Albic Luvisol from the Třesín 2 site is acid in the upper part of the profile, then weakly acid in the Bt horizons, and basic in the $\mathrm{Ck}$ horizon. The $\Delta \mathrm{pH}$ values are $>1$ in some cases. Similar differences in $\mathrm{pH}$ values have been reported by Gallardo Lancho (1999). This may be connected with the fact that the $\mathrm{pH}_{\mathrm{H} 2 \mathrm{O}}$ refers to the acidity of soil solution. On the other hand, the $\mathrm{pH}_{\mathrm{KCl}}$ refers to the acidity in the soil solution, plus the reserve acidity in the colloids. The presence of $\mathrm{CaCO}_{3}$ in the $\mathrm{Ck}$ horizons is affected by the character of parent material. Different content of $\mathrm{CaCO}_{3}$ is probably related with local conditions of loess.

The observed trend in values of cation exchange capacity throughout the profiles was not very clear. This distribution is probably connected with the content of individual minerals and also with $\mathrm{pH}$ values. Very high cation exchange capacity was found in the upper part of Paní hora profile. This value is influenced by the high content of organic matter.

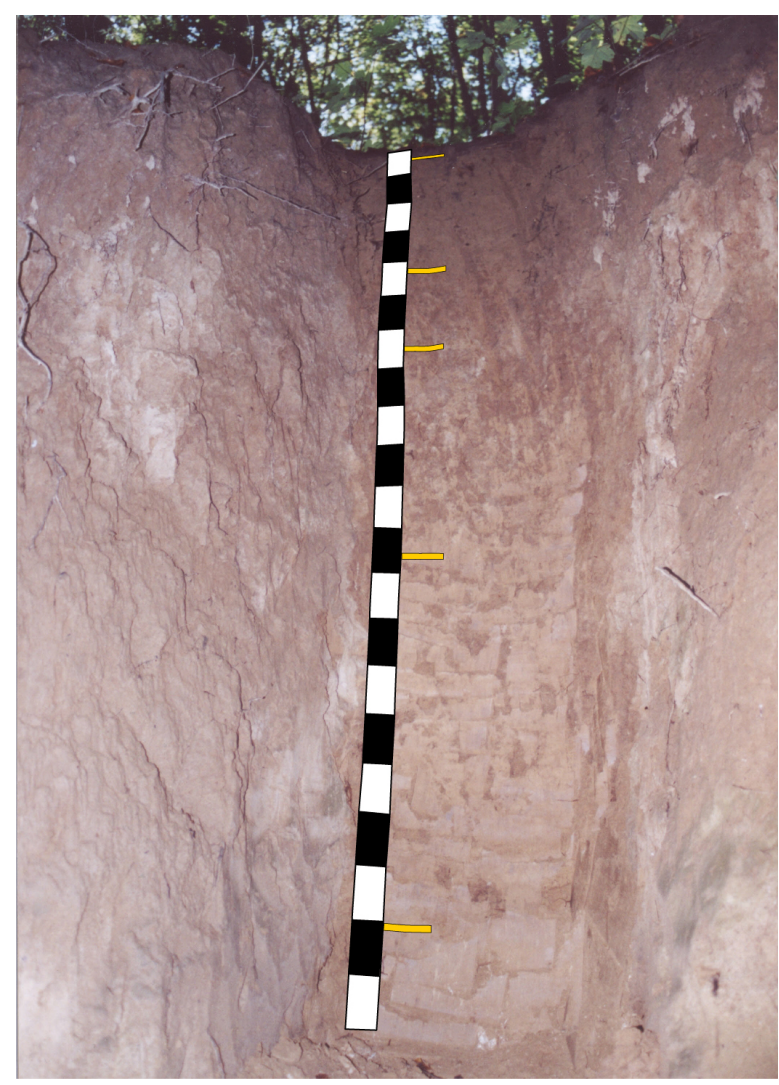

Fig. 5 Soil profile from the Třesín 2 site, each step on the scale bar corresponds to $10 \mathrm{~cm}$ (photo A. Žigová).

Table 3 Chemical properties.

\begin{tabular}{lccccc}
\hline Profile & $\begin{array}{c}\text { Depth } \\
\mathrm{cm}\end{array}$ & $\mathrm{pH}_{\mathrm{H} 2 \mathrm{O}}$ & $\mathrm{pH}_{\mathrm{KCl}}$ & $\begin{array}{l}\mathrm{CaCO}_{3} \\
\%\end{array}$ & $\begin{array}{l}\mathrm{CEC} \\
\mathrm{cmol}\end{array}{ }^{(\mathrm{p}+)} / \mathrm{kg}$ \\
\hline Blato & $0-24$ & 7.14 & 6.72 & & 13.60 \\
& $24-43$ & 7.52 & 7.03 & & 13.01 \\
& $43-78$ & 7.16 & 6.54 & & 14.87 \\
& $78-117$ & 7.22 & 6.68 & & 12.94 \\
& $117-170$ & 8.12 & 7.40 & 14.0 & 16.52 \\
\hline Kněževes & $0-30$ & 6.80 & 6.41 & & 21.36 \\
& $30-48$ & 6.88 & 6.52 & & 21.63 \\
& $48-85$ & 6.88 & 6.18 & & 22.90 \\
& $85-130$ & 7.62 & 7.31 & 7.5 & 17.06 \\
\hline Paní hora & $0-4$ & 5.13 & 4.37 & & 60.04 \\
& $4-11$ & 3.95 & 3.36 & & 28.99 \\
& $11-25$ & 3.81 & 3.29 & & 15.13 \\
& $25-38$ & 4.01 & 3.37 & & 15.74 \\
& $38-62$ & 4.49 & 3.50 & & 24.48 \\
& $62-122$ & 5.26 & 4.22 & & 20.57 \\
& $122-209$ & 7.53 & 7.17 & 5.2 & 14.99 \\
\hline Třesín 2 & $0-4$ & 4.87 & 3.90 & & 19.47 \\
& $4-43$ & 4.80 & 3.27 & & 9.79 \\
& $43-65$ & 5.26 & 3.81 & & 10.07 \\
& $65-117$ & 5.51 & 4.22 & & 14.46 \\
& $117-191$ & 5.35 & 3.97 & & 15.83 \\
& $191-221$ & 7.91 & 7.28 & 9.0 & 12.79 \\
\hline
\end{tabular}

CEC - cation exchange capacity 


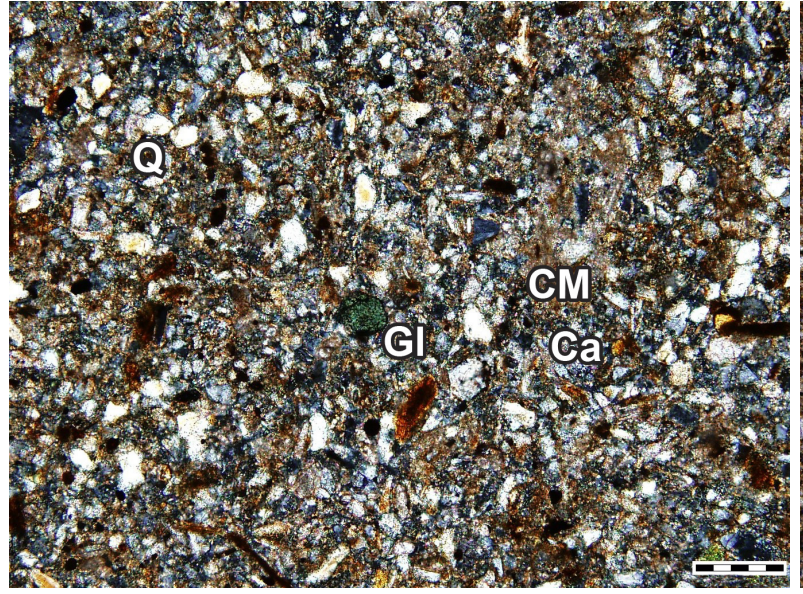

Fig. 6 A photomicrograph of a thin section of the $\mathrm{Ck}$ horizon from the Blato site, crossed polars, each step on the scale bar corresponds to $0.04 \mathrm{~mm}, \mathrm{CM}$ - clay minerals, Q - quartz, $\mathrm{Ca}$ - calcite, Gl - glauconite (photo A. Žigová and M. Št'astný).

The results indicate that the soil development of Albic Luvisols proceeded in more acid conditions than the development of Luvic Chernozem. The values of $\mathrm{pH}$ in the horizons correspond to the content of $\mathrm{CaCO}_{3}$ and probably also of secondary forms of carbonates. Morphological analysis of soils shows the presence of pseudomycelias in all $\mathrm{Ck}$ horizons, but hard carbonate concretions were found only in the Blato profile. The $\Delta \mathrm{pH}$ values $>1$ were documented in the Albic Luvisols. These values may be related with the content of clay fraction or the cation exchange capacity. In the case of $\mathrm{E}$ horizons, this value is influenced by the relatively low cation exchange capacity. The $\Delta \mathrm{pH}>1$ for Bt horizons is probably connected with an elevated content of clay fraction.

\section{SOIL ORGANIC MATTER}

The distribution of organic carbon, total nitrogen and $\mathrm{C} / \mathrm{N}$ ratio in the soil profiles is presented in Table 4. Values of organic carbon and total nitrogen are the highest in the Ap and Ah horizons in all soils. The highest values of this parameter were found in protected nature reserves at the sites of Paní hora and Třesín 2. The content of organic matter decreases gradually down the profiles of Luvic Chernozem, which corresponds with the results of Pospíšil (1980). Albic Luvisol is characterized by a rapidly decreasing content of organic matter in soil profiles. The content of organic carbon is higher in the Bth horizons than in the $\mathrm{Bt}$ horizons. The $\mathrm{C} / \mathrm{N}$ value showed a variable enrichment of soil organic matter by nitrogen.

The results show that the quantity and quality of soil organic matter was probably connected with the source of biomass and the type of land use.

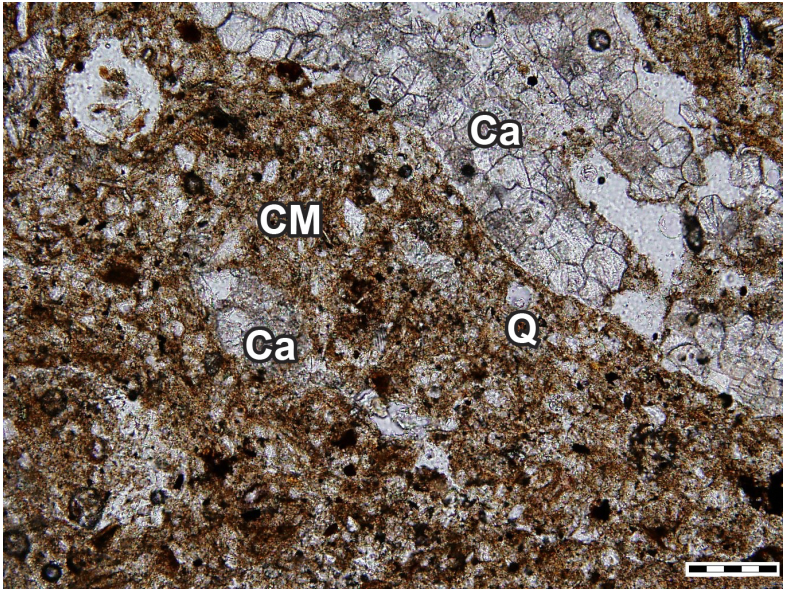

Fig. 7 A photomicrograph of a thin section of the $\mathrm{Ck}$ horizon from the Kněževes site, crossed polars, each step on the scale bar corresponds to $0.04 \mathrm{~mm}, \mathrm{CM}$ - clay minerals, Q - quartz, $\mathrm{Ca}$ - calcite (photo A. Žigová and M. Št’astný).

Table 4 Soil organic matter.

\begin{tabular}{llclr}
\hline Profile & $\begin{array}{l}\text { Depth } \\
\mathrm{cm}\end{array}$ & \multicolumn{1}{l}{$\begin{array}{l}\mathrm{C}_{\mathrm{ox}} \\
\%\end{array}$} & $\begin{array}{l}\mathrm{N}_{\mathrm{t}} \\
\mathrm{\%}\end{array}$ & $\mathrm{C} / \mathrm{N}$ \\
\hline Blato & $0-24$ & 1.69 & 0.15 & 11.27 \\
& $24-43$ & 1.29 & 0.12 & 10.75 \\
& $43-78$ & 0.93 & 0.08 & 11.62 \\
& $78-117$ & 0.45 & 0.04 & 11.25 \\
& $117-170$ & 0.13 & 0.01 & 13.00 \\
\hline Kněževes & $0-30$ & 1.41 & 0.16 & 8.81 \\
& $30-48$ & 1.38 & 0.16 & 8.63 \\
& $48-85$ & 0.48 & 0.05 & 9.60 \\
& $85-130$ & 0.38 & 0.05 & 7.60 \\
\hline Paní hora & $0-4$ & 13.99 & 0.85 & 16.46 \\
& $4-11$ & 4.08 & 0.19 & 21.47 \\
& $11-25$ & 0.82 & 0.05 & 16.40 \\
& $25-38$ & 0.61 & 0.05 & 12.20 \\
& $38-62$ & 0.40 & 0.05 & 8.00 \\
& $62-122$ & 0.44 & 0.04 & 11.00 \\
& $122-209$ & 0.37 & 0.03 & 12.33 \\
\hline Třesín 2 & $0-4$ & 3.29 & 0.29 & 11.34 \\
& $4-43$ & 0.39 & 0.05 & 7.80 \\
& $43-65$ & 0.24 & 0.03 & 8.00 \\
& $65-117$ & 0.14 & 0.03 & 4.67 \\
& $117-191$ & 0.16 & 0.03 & 5.33 \\
& $191-221$ & 0.14 & 0.03 & 4.67 \\
\hline
\end{tabular}

$\mathrm{C}_{\mathrm{ox}}-$ organic carbon, $\mathrm{N}_{\mathrm{t}}-$ total nitrogen

\section{PETROGRAPHY OF PARENT MATERIAL}

Parent material of the individual soil profiles was the subject of petrographic studies.

Loess from the Blato site (Figure 6) is uniformly granular with very frequent relatively large grains of quartz up to $1 \mathrm{~mm}$ in size. These grains are larger than the other grains in the matrix. Feldspars are smaller, 


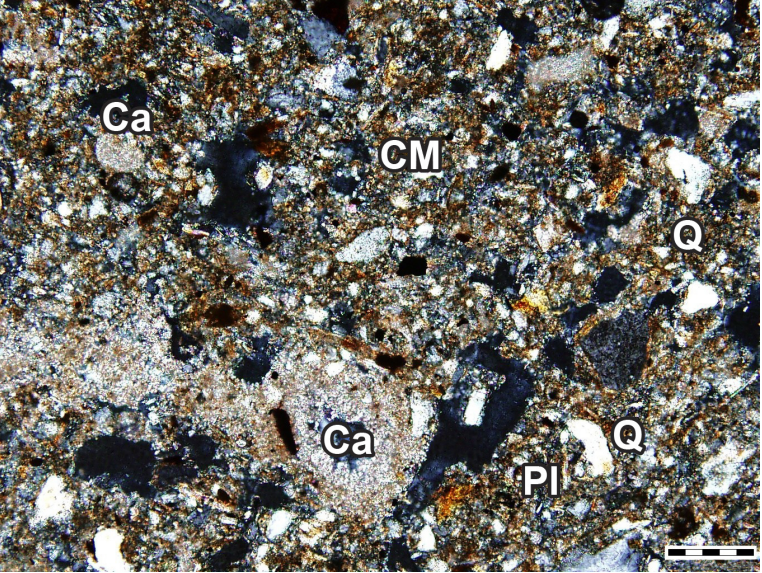

Fig. 8 A photomicrograph of a thin section of the $\mathrm{Ck}$ horizon from the Paní hora site, crossed polars, each step on the scale bar corresponds to $0.04 \mathrm{~mm}, \mathrm{CM}$ - clay minerals, $\mathrm{Ca}$ - calcite, Q - quartz, Pl - plagioclase (photo A. Žigová and M. Št'astný).

$0.5 \mathrm{~mm}$ in size. The amount of green aggregates of glauconite is small. These grains, together with larger quartz grains, are derived from the underlying Cretaceous rocks. The groundmass consists of clay minerals which are brown-coloured iron oxides and hydrooxides. Secondarily crystallized calcite grains locally fill channels after root decay.

Loess of $\mathrm{Ck}$ horizon from the Kněževes profile (Figure 7) is generally very fine-grained, composed of clay minerals, small grains of quartz and feldspar. Groundmass also includes clusters of larger quartz grains and also small amount of green glauconite aggregates. This material comes from the underlying Cretaceous sediments. Channels after decomposed roots are often filled with secondarily crystallized calcite grains.

Loess from the site of Paní hora (Figure 8) is medium-grained. Clay matrix consists of small grains of quartz, feldspars and irregularly dispersed larger quartz grains, and also clusters of secondarily crystallized calcite grains.

Loess of Ck horizon from Třesín 2 (Figure 9) is very fine-grained, well sorted, and composed of quartz grains, relatively large amounts of feldspars and clay minerals. Channels after decomposed roots are often filled with secondarily crystallized calcite grains.

Petrography of thin sections of loess allow to document the character of individual $\mathrm{Ck}$ horizons. Matrix of all studied sites consists of quartz and various forms of carbonate. Groundmass of the $\mathrm{Ck}$ horizons from the Bohemian Cretaceous Basin (Blato and Kněževes) consists of glauconite and differs in the content and distribution of larger quartz grains. These grains are dispersed at the Blato site but typically clustered in the Kněževes area. Loess from Paní hora contains irregularly scattered larger quartz grains. The

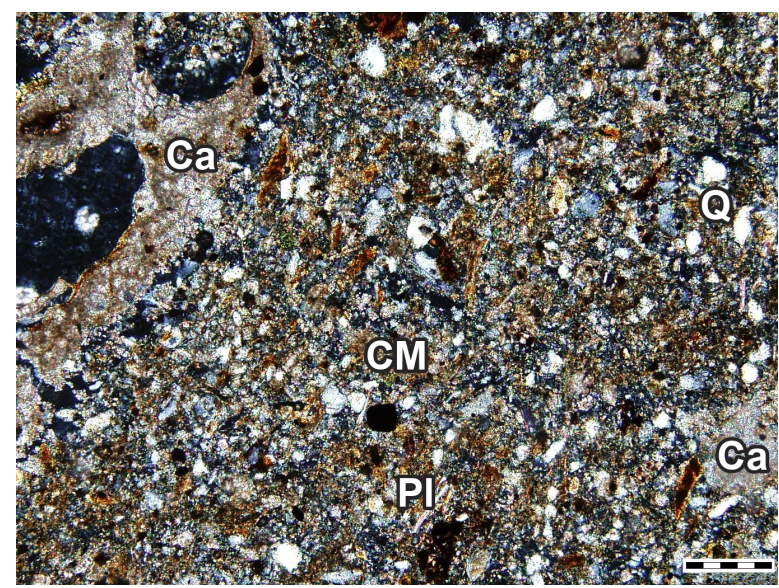

Fig. 9 A photomicrograph of a thin section of the $\mathrm{Ck}$ horizon from the Třesín 2 site, crossed polars, each step on the scale bar corresponds to $0.04 \mathrm{~mm}, \mathrm{CM}$ - clay minerals, $\mathrm{Ca}$ - calcite, $\mathrm{Q}$ - quartz, Pl - plagioclase (photo A. Žigová and M. Št'astný).

Ck horizon at the Třesín 2 site has a relatively high content of feldspar; larger quartz grains are rare.

\section{MINERALOGY OF CLAY FRACTION OF SOILS}

Mineral composition of the clay fraction is given in Table 5. X-ray diffractograms of the clay fraction are given in Figure 10 (Blato, Bth2 horizon), Figure 11 (Kněževes, Bth horizon), Figure 12 (Paní hora, Bt2 horizon) and Figure 13 (Třesín 2, Bt2 horizon).

Clay fraction from the Blato site is dominated by quartz (3.34 $\AA)$, kaolinite $(7.15 \AA)$, illite $(9.98 \AA)$. Kfeldspar $(3.24 \AA)$ and plagioclase $(3.19 \AA)$ are partly preserved. Smectite with basal reflections about $14 \AA$ (ethylene glycol solvated $16.9 \AA$ and heating at $550{ }^{\circ} \mathrm{C} 10.01 \AA$ ) is derived from the underlying Cretaceous sediments. Chlorite with basal reflections about $14 \AA$, unchanged after ethylene glycol solvation and heating at $550^{\circ} \mathrm{C}$, occurs in small amounts.

The Kněževes profile is characterized by a high content of quartz in the clay fraction. Individual soil horizons have variable quantity of illite and kaolinite. Smectite is also present in the soil profile. They are probably derived from the underlying Cretaceous sediments. Chlorite is present in a similar amount as smectite. Lepidocrocite $(6.18 \AA)$ was detected in the Ap and Ah horizons.

The most common minerals of clay fraction of the soil sequence at Paní hora are quartz, kaolinite and illite. Bt1 and Bt2 horizons have elevated contents of illite. The distribution of kaolinite in the soil profile is relatively stable although some abnormities can be observed. Small amounts of chlorite are present in all profiles.

Mineral composition of clay fraction at Třesín 2 is slightly different from that in the previous areas. The soil profile is indeed rich in quartz. The relatively 


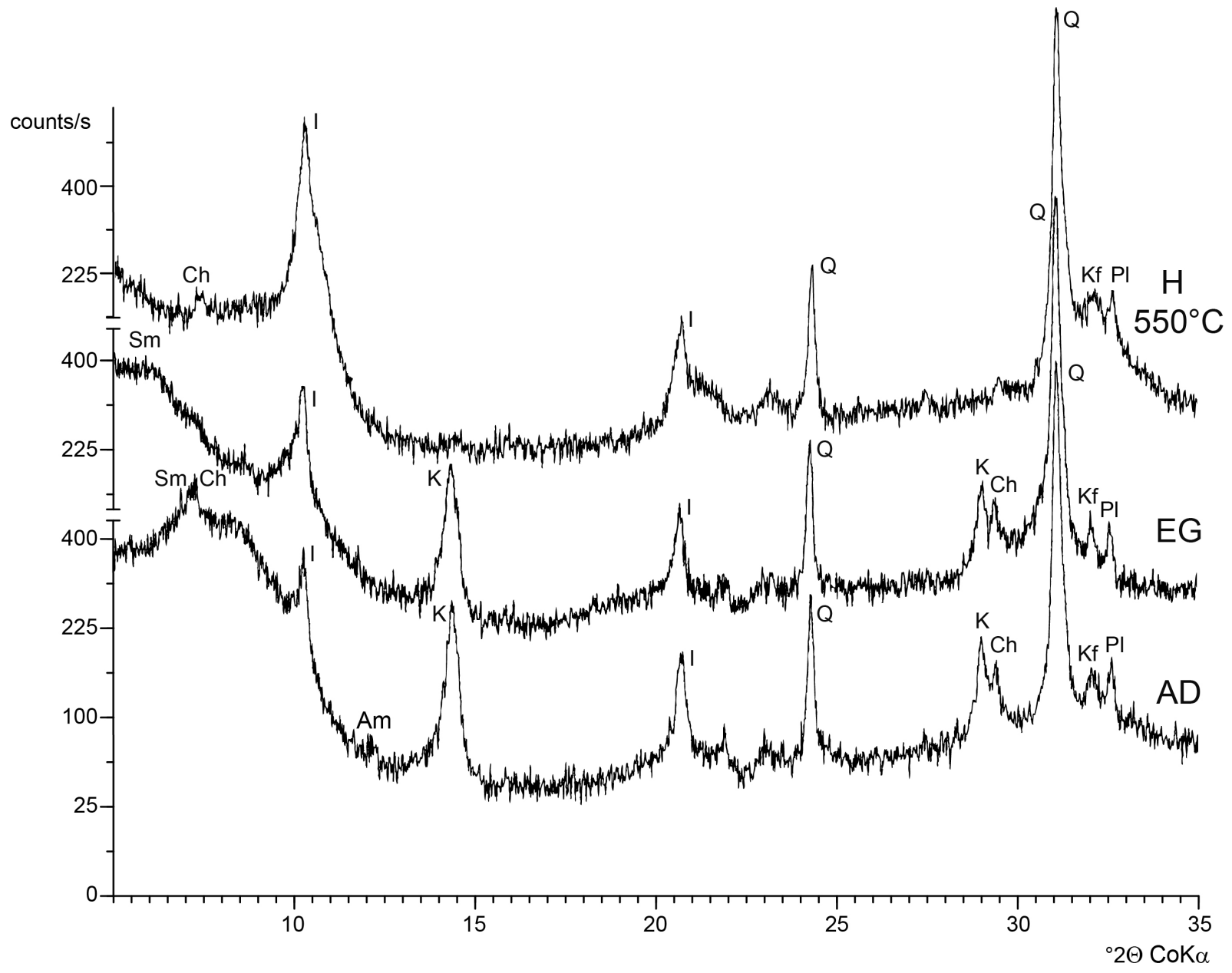

Fig. $10 \mathrm{X}$ ray-diffractogram of clay fraction Bth2 horizon from Blato, AD - air-dried, EG ethylene glycol solvated, H - heating, $\mathrm{Ch}$ - chlorite, I - illite, $\mathrm{K}$ - kaolinite, Sm - smectite, Q - quartz, Kf - Kfeldspare, $\mathrm{Pl}$ - plagioclase, Am - amphibole.

Table 5 Mineral composition of the clay fraction.

\begin{tabular}{|c|c|c|c|c|c|c|c|c|c|c|c|}
\hline Profile & $\begin{array}{l}\text { Depth } \\
\mathrm{cm}\end{array}$ & $\begin{array}{l}\mathrm{Ch} \\
\%\end{array}$ & $\begin{array}{l}\mathrm{I} \\
\%\end{array}$ & $\begin{array}{l}\mathrm{K} \\
\%\end{array}$ & $\begin{array}{c}\mathrm{Sm} \\
\%\end{array}$ & $\begin{array}{l}\mathrm{Q} \\
\%\end{array}$ & $\begin{array}{r}\mathrm{Kf} \\
\%\end{array}$ & $\begin{array}{l}\mathrm{P} 1 \\
\%\end{array}$ & $\begin{array}{l}\text { Am } \\
\%\end{array}$ & $\begin{array}{l}\text { Gy } \\
\%\end{array}$ & $\begin{array}{l}\mathrm{Le} \\
\%\end{array}$ \\
\hline \multirow[t]{5}{*}{ Blato } & $0-24$ & 4 & 26 & 21 & 7 & 36 & 6 & 0 & 0 & 0 & 0 \\
\hline & $24-43$ & 0 & 20 & 24 & 7 & 39 & 6 & 4 & 0 & 0 & 0 \\
\hline & $43-78$ & 3 & 13 & 12 & 3 & 56 & 7 & 6 & 0 & 0 & 0 \\
\hline & $78-117$ & 3 & 18 & 18 & 6 & 41 & 6 & 7 & 1 & 0 & 0 \\
\hline & $117-170$ & 2 & 13 & 15 & 7 & 49 & 8 & 6 & 0 & 0 & 0 \\
\hline \multirow[t]{4}{*}{ Kněževes } & $0-30$ & 4 & 10 & 9 & 5 & 59 & 5 & 3 & 0 & 0 & 5 \\
\hline & $30-48$ & 2 & 12 & 10 & 2 & 59 & 3 & 4 & 0 & 0 & 8 \\
\hline & $48-85$ & 3 & 9 & 14 & 9 & 56 & 5 & 4 & 0 & 0 & 0 \\
\hline & $85-130$ & 5 & 13 & 10 & 2 & 54 & 6 & 9 & 1 & 0 & 0 \\
\hline \multirow[t]{7}{*}{ Paní hora } & $0-4$ & 1 & 13 & 11 & 0 & 57 & 8 & 9 & 0 & 0 & 1 \\
\hline & $4-11$ & 2 & 16 & 20 & 0 & 51 & 6 & 5 & 0 & 0 & 0 \\
\hline & $11-25$ & 3 & 13 & 20 & 0 & 52 & 7 & 5 & 0 & 0 & 0 \\
\hline & $25-38$ & 5 & 29 & 13 & 3 & 35 & 8 & 7 & 0 & 0 & 0 \\
\hline & $38-62$ & 4 & 30 & 20 & 2 & 28 & 10 & 6 & 0 & 0 & 0 \\
\hline & $62-122$ & 6 & 35 & 16 & 0 & 28 & 9 & 6 & 0 & 0 & 0 \\
\hline & $122-209$ & 3 & 22 & 16 & 6 & 38 & 8 & 7 & 0 & 0 & 0 \\
\hline \multirow[t]{6}{*}{ Třesín 2} & $0-4$ & 5 & 16 & 7 & 1 & 50 & 9 & 11 & 0 & 0 & 1 \\
\hline & 4-43 & 6 & 8 & 4 & 0 & 40 & 22 & 18 & 2 & 0 & 0 \\
\hline & $43-65$ & 5 & 14 & 6 & 0 & 44 & 14 & 14 & 2 & 1 & 0 \\
\hline & $65-117$ & 3 & 20 & 0 & 0 & 56 & 8 & 10 & 2 & 0 & 1 \\
\hline & $117-191$ & 3 & 19 & 4 & 0 & 45 & 15 & 12 & 2 & 0 & 0 \\
\hline & $191-221$ & 2 & 16 & 7 & 2 & 52 & 8 & 11 & 1 & 0 & 1 \\
\hline
\end{tabular}

$\mathrm{Ch}$ - chlorite, I - illite, $\mathrm{K}$ - kaolinite, Sm - smectite, Q - quartz, Kf - feldspare, Pl - plagioclase, Am - amphibole, Gy gypsum, Le - lepidocrocite 


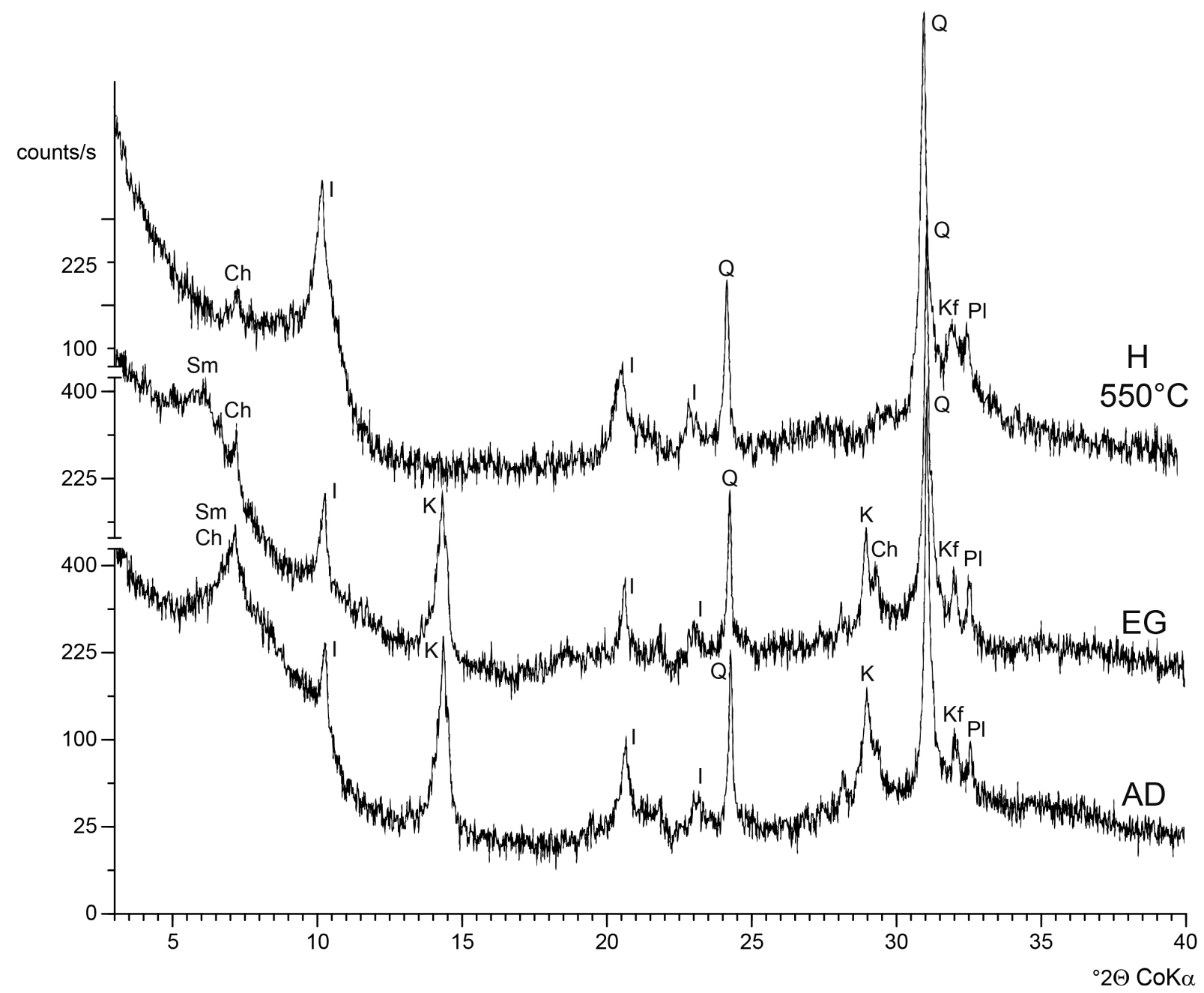

Fig. 11 X ray-diffractogram of clay fraction Bth horizon from Kněževes, AD - air-dried, EG ethylene glycol solvated, H - heating, Ch - chlorite, I - illite, K - kaolinite, Sm - smectite, Q - quartz, Kf - Kfeldspare, $\mathrm{Pl}$-plagioclase.

high contents of feldspar and the presence of amphibole $(8.38 \AA)$ illustrate the effect of the surrounding flysch rocks. Bt1 and $\mathrm{Bt} 2$ horizons have elevated contents of illite. Small amounts of chlorite are present in all profiles.

All studied profiles show some similarity in mineral composition, such as the dominant occurrence of quartz, illite and kaolinite This portion of mineral phases was also described by Sirový (1966).

\section{PEDOGENESIS ON LOESS OVERLYING CRETACEOUS SEDIMENTS}

Soils developed directly on Cretaceous sediments are predominantly Haplic Leptosols or Haplic Cambisols (Zigova et al., 2008). These sediments in the studied regions were covered with loess which led to the development of Luvic Chernozems under local conditions. Their evolution is connected with the pedogenetic process of humification which is accompanied by a relatively slight process of pedogenetic clay differentiation.
Human activity influenced the upper parts of soil profiles. These conditions result in the following succession of horizons: Ap-Ah-Bth1-Bth2-Ck (Blato) and Ap-Ah-Bth-Ck (Kněževes). The intensity of humification (content of $\mathrm{Cox}$ and $\mathrm{Nt}$ ) and ploughing activity (thickness of Ap horizons) and also the thickness of Ah horizons are similar. Although the Blato profile shows a higher thickness of Bth horizon, the intensity of pedogenetic clay differentiation (greyish brown coatings, content of clay fraction) is higher at the Kněževes site. The intensity of pedogenetic clay differentiation is influenced by $\mathrm{pH}$ conditions. Driessen et al. (2001) reported that more acid conditions are favourable for this process. The most common minerals of clay fraction of the individual soil horizons are quartz, illite and kaolinite; this corresponds with the results of Drewnik et al. (2014). The presence and the type of secondary carbonates in the $\mathrm{Ck}$ horizons are controlled by the content of $\mathrm{CaCO}_{3}$ in loess. 


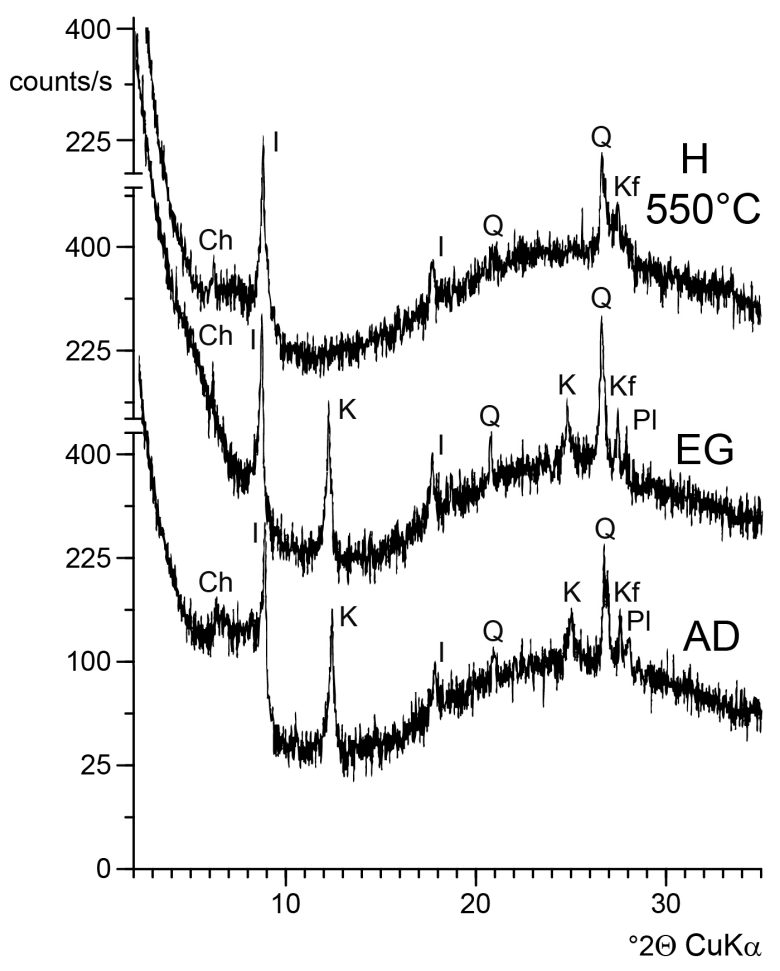

Fig. $12 \mathrm{X}$ ray-diffractogram of clay fraction $\mathrm{Bt} 2$ horizon from Paní hora, AD - air-dried, EG ethylene glycol solvated, $\mathrm{H}$ - heating, $\mathrm{Ch}-$ chlorite, I - illite, K - kaolinite, Q - quartz, $\mathrm{Kf}-\mathrm{K}$-feldspare, $\mathrm{Pl}$ - plagioclase.

\section{PEDOGENESIS ON LOESS OVERLYING DEVONIAN LIMESTONES}

If the soils are developed directly on limestones, the pedogenetic process results in Rendzic Leptosols. This fact has been described by Žigová et al. (2014). Devonian limestones at the studied sites were covered by loess, which led to the development of Albic Luvisols under local conditions. The research was conducted in national nature reserves. These conditions result in the following succession of horizons: $\mathrm{O}-\mathrm{Ah}-\mathrm{AhE}-\mathrm{E}-\mathrm{EBt1}-\mathrm{Bt1}-\mathrm{Bt} 2-\mathrm{Ck}$ (Paní hora) and O-Ah-E-EBt1-Bt1-Bt2-Ck (Třesín 2). Although the highest values of $\mathrm{Cox}$ and $\mathrm{Nt}$ were found in at the Paní hora and Třesín 2 sites, the qualitative parameter of soil organic matter $(\mathrm{C} / \mathrm{N})$ shows a relatively slight process of litter formation and humification. The soil development is primarily conected with the process of pedogenetic clay differentation and formation of $\mathrm{Bt}$ horizons. This fact is also documented by the presence of E horizon. The Paní hora profile shows a smaller thickness of $\mathrm{Bt}$ horizon but a more intensive process of pedogenetic clay differentiation (brown coatings, content of clay fraction) than the Třesín 2 site. This is probably a result of more acid conditions in the Paní hora profile. Bt horizons have elevated contents of illite. Clay fraction of Albic Luvisol is also dominated by quartz and kaolinite. Similar results were described by

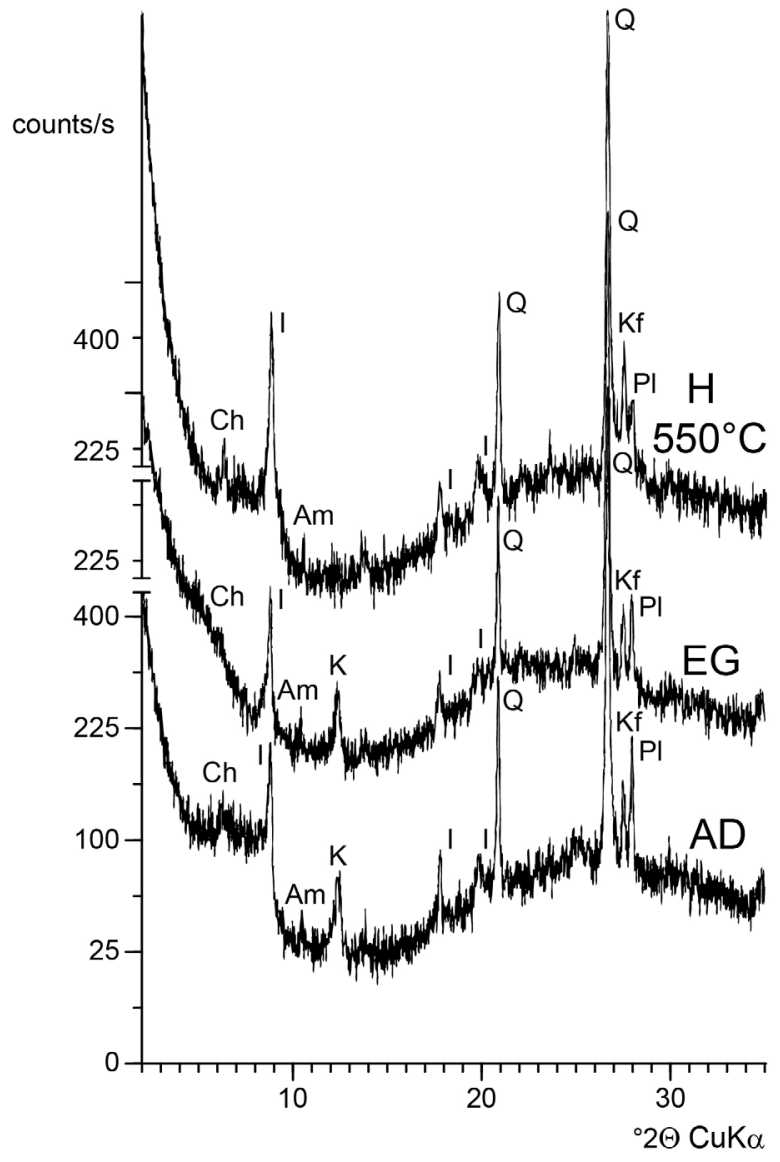

Fig. $13 \mathrm{X}$ ray-diffractogram of clay fraction $\mathrm{Bt} 2$ horizon from Třesín 2, AD - air-dried, EG ethylene glycol solvated, $\mathrm{H}$ - heating, $\mathrm{Ch}-$ chlorite, I - illite, K - kaolinite, Q - quartz, $\mathrm{Kf}$ - K-feldspare, Pl - plagioclase, Am amphibole.

Szymański et al. (2014). The presence and the type of secondary carbonates in the $\mathrm{Ck}$ horizons is related with the local distribution of loess.

\section{CONCLUSION}

Soil development on loess under the same climatic conditions in the regions of Cretaceous sediments and Devonian limestone shows differences which are largely connected with geological conditions.

The main pedogenetic process for soil cover of the Bohemian Cretaceous Basin is humification. Pedogenetic clay differentiation is relatively slight. Ploughing influenced upper $24-30 \mathrm{~cm}$ of the soil profiles. The studied sites are covered by Luvic Chernozem.

The main pedogenetic process for soil on loess underlain by Devonian limestones is intense pedogenetic clay differentiation. Processes of litter formation and humification are of lesser importance. Albic Luvisols were classified in these regions.

The studied soils are dominated by silt fraction which is characteristic for soils developed on loess. The quantity of clay fraction in the $\mathrm{Bt}$ and $\mathrm{Bth}$ 
horizons indicates process of pedogenetic clay differentiation.

The process of pedogenetic clay differentiation was influenced by the $\mathrm{pH}$ value. It is significant under more acid conditions, which is typical for Albic Luvisol.

The content of organic matter decreases gradually down the profile of Luvic Chernozem and rapidly in Albic Luvisol. The content of organic carbon is higher in the Bth horizons than in the $\mathrm{Bt}$ horizons. The quantity and quality of soil organic matter was probably connected with the source of biomass and type of land use.

Petrography of thin sections of loess shows features of individual $\mathrm{Ck}$ horizons. Clay matrix of loess at all studied sites consists of quartz and various forms of carbonate. Only the $\mathrm{Ck}$ horizons in the Bohemian Cretaceous Basin (Blato and Kněževes) revealed the presence of glauconite and coarse quartz grains.

Mineral composition of soils on loess reflects geological setting in the individual regions. The most common minerals of clay fraction of the studied soil samples are quartz, illite and kaolinite. Small amounts of chlorite are present in all profiles. The Bt1 and Bt2 horizons of Albic Luvisols have elevated illite contents.

\section{ACKNOWLEDGMENTS}

This research was financially supported by institutional project RVO 67985831 of the Institute of Geology of the CAS, v. v. i. The authors thank J. Rajlichová for technical assistance.

\section{REFERENCES}

Baize, D.: 1983, Soil science analyses: a guide to current use. John Wiley \& Sons Ltd. Chichester, England.

Bronger, A.: 2003, Corellation of loess-paleosol sequences in East and Central Asia with SE Europe: toward a continental Quaternary pedistratigraphy and paleoclimatic history. Quaternary International, 106-107, 11-31. DOI: 10.1016/S1040-6182(02)00159-3

Chlupáč, I.: 1974, The Geological Foundation of the Bohemian Karst. Bohemia centralis, 3, 58-79, (in Czech).

Chlupáč, I. and Svoboda, J: 1963, Geological condition of the Devonian in the Konice-Mladeč Area on the Drahany Plateau. Sborník Ústředního ústavu geologického - Oddíl geologický, XXVIII, 347-386, (in Czech).

Cilek, V.: 2001, The loess deposits of the Bohemian Massiff: silt provenance, paleometeorology and loessification processes. Quaternary International, 76/77, 123-138.

DOI: $10.1016 / \mathrm{S} 1040-6182(00) 00096-3$

Crha, J.: 1979, Devonian of the Konice-Mladeč stripe and its economic exploration. Sborník Geologický průzkum Ostrava, 19, 77-91, (in Czech).

Dodonov, A.E., Sadchikova, T.A., Sedov, S.N., Simakova, A.N. and Zhou, L.P: 2006, Multidisciplinary approach for paleoenvironmental reconstruction in loesspaleosol studies of the Darai Calon section, Southern
Tajikistan. Quaternary International, 152-153: 45-58. DOI: 10.1016/j.quaint.2005.12.001

Drewnik, M., Skiba, M., Szymański, W. and Żyła M.: 2014, Mineral composition vs. soil forming processes in loess soils - A case study from Kraków (Southern Poland). Catena, 119, 166-173. DOI: 10.1016/j.catena.2014.02.012

Driessen, P., Deckers, J., Spaargaren, O. and Nachtergaele, F.: 2001, Lecture notes on the major soils of the world. FAO, Rome. ISBN 92-5-104637-9.

Frechen, M., Zander, A., Cílek, V. and Ložek, V.: 1999, Loess chronology of the Last Interglacial/Glacial cycle in Bohemia and Moravia, Czech Republic. Quaternary Science Reviews, 18 (13), 1467-1493. DOI: 10.1016/S0277-3791(98)00087-0

Gallardo Lancho, J.F.: 1999, Relationship between total extractable organic carbon and some parameters of soils from western Spain. Humic substances in the environment, 1 (3-4), 15-20.

Gunal, H. and Ransom, M.D.: 2006, Genesis and micromorphology of loess-derived soils from central Kansas. Catena, 65 (3), 226-236. DOI:10.1016/j.catena.2005.11.018

Haase, D., Fink, J., Haase, G., Ruske, R., Pécsi, M., Richter, H., Altermann, M. and Jäger, K. -D.: 2007, Loess in Europe - its spatial distribution based on a European Loess Map, scale 1:2,500,000. Quaternary Science Reviews, 26 (9-10), 201-1312. DOI: $10.1016 /$ j.quascirev.2007.02.003

Holásek, O., Tíma, V. and Rambousek, P.: 1989, Geological map of the Czech Republic. Sheet 13-42, Pardubice. Czech Geological Survey, Prague, (in Czech).

Hradilová, J. and Št'astný, M.: 1994, Changes in the Clay Fraction Mineral Composition in a Loess Profile of the Last Interglacial and Early Glacial in PrahaSedlec. Acta Universitatis Carolinae - Geologica, 38, (2-4), 229-238.

Huang, C.-Q., Tan, W.-F., Wang, M.-K., and Koopal, L.K.: 2014, Characteristics of the fifth paleosol complex $\left(\mathrm{S}_{5}\right)$ in the southernmost part of the Chinese Loess Plateau and its paleo-environmental significance. Catena, 122, 130-139. DOI: 10.1016/j.catena.2014.06.009

IUSS Working Group WRB: 2014, World Reference Base for Soil Resources 2014. International soil classification system for naming soils and creating legends for soil maps. World Soil Resources Reports 106. FAO, Rome.

Jahn, R., Blume, H.P., Asio, V.B., Spaargaren, O. and Schad, P.: 2006, Guidelines for soil description. Fourth edition. FAO, Rome.

Khormali, F.and Ajami, M.: 2011, Pedogenetic investigation of soil degradation on a deforested loess hillslope of Golestan Province, Northern Iran. Geoderma, 167168, 274-283. DOI:10.1016/j.geoderma.2011.07.030

Khormali, F., Ghergherechi, S, Kehl, M. and Ayoubi, S.: 2012, Soil formation in loess-derived soils along a subhumid to humid climate gradient, Northeastern Iran. Geoderma, 179-180, 113-122. DOI:10.1016/j.geoderma.2012.02.002

Kukla, J. and Ložek, V.: 1961, Loesses and related deposits. Survey of Czechoslovak Quaternary. Instytut Geologiczny - Prace, XXXIV (1), 11-28.

Mísař, Z., Dudek, A., Havlena, V. and Weiss, J.: 1983, Geology of Czechoslovakia I. Bohemian Massif. SPN, Prague, (in Czech). 
Němeček, J.: 1981, Basic diagnostic features and soil classification of Czechoslovakia. Studie ČSAV 8. Academia, Prague, (in Czech).

Nemecz, E., Pécsi, M., Hartyáni, Z. and Horváth, T.: 2000, The origin of the silt size quartz grains and minerals in loess. Quaternary International, 68-71, 199-208.

Pécsi, M.: 1990, Loess is not just the accumulation of dust. Quaternary International, 7-8, 1-21. DOI: 10.1016/1040-6182(90)90034-2

Perederij, V.I.: 2001, Clay mineral composition and paleoclimatic interpretation of the Pleistocene deposits of Ukraine. Quaternary International, 76-77, 113-121. DOI: $10.1016 / \mathrm{S} 1040-6182(00) 00095-1$

Pospíšil, F.: 1980, Content and composition of humus in the soil in the Czech lands. Studie ČSAV 14. Academia, Prague, (in Czech).

Quitt, E.: 1971, Climatic regions of the Czechoslovakia. Studia Geographica, 16, Československá akademie věd, Geografický ústav, Brno, (in Czech).

Š́ály, R. and Mihálik, A.: 1970, Clay minerals in main soils of the Slovakia. Seria pedologica 7. Vydavatel'stvo Slovenskej akadémie vied, Bratislava, (in Slovak).

Sirový, V.: 1964, Die Charasteristik der Tonfraction einiger Böden über löß und lößlehm. Rostlinná výroba, 10, No. 5-6, 555-565.

Sirový, V.: 1966, Clay minerals in soils of the ČSSR. Rostlinná výroba, 12, No. 6, 697-700, (in Czech).

Smolíková, L.:1972, Genesis of fossil soil types in the loess series of Czechoslovakia. Acta Universitatis Carolinae, Geographica, 2, 45-48.

Smolíková, L.: 1984, On the Development of Pleistocene Soils in Czechoslovakia. 33-38. In: Pécsi, M. (Ed.) Lithology and stratigraphy of Loess and Paleosols. Geographical Research Institute - Hungarian Academy of Sciences, Budapest.

Sokolova, T.A., Zaidel'man, F.R. and Ginzburg, T.M.: 2010, Clay Minerals in Chernozem-like Soils of Mesodepression in the Northern Forest-Steppe of European Russia, Eurasian Soil Science, 43 (1), 76-84. DOI: $10.1134 / \mathrm{S} 1064229310010102$

Št'astný, M.: 1997, Clay minerals in a loess profile at Dolní Věstonice. Acta Montana, A, No. 11 (104), 73-77.
Szymański, W., Skiba, M., Nikorych, V.A. and Kuligiewicz, A.: 2014, Nature and formation of interlayer fillings in clay minerals in Albeluvisols from the Carpathian Foothills, Poland. Geoderma, 235-236, 369-409. DOI: $10.1016 /$ j.geoderma.2014.08.001

Tomášek, M.: 1998, Regional characteristic of loesses of the Czech Republic. Zprávy o geologických výzkumech v roce 1997, 27-29, (in Czech).

Valla, M., Kozák, J., Němeček, J., Matula, S., Borůvka, L. and Drábek, O.: 2002, Laboratory manual of Soil Science. Česká zemědělská univerzita, Katedra pedologie a geologie AF, Prague, (in Czech).

Vejlupek, M.: 1988, Geological map of the Czech Republic. Sheet 12-23 Kladno. Czech Geological Survey, Prague, (in Czech).

Žigová, A., Št’astný, M. and Hladil, J.: 2014, Mineral composition of Rendzic Leptosols in protected areas of the Czech Republic. Acta Geodyn. Geomater., 11, No. 1 (173), 77-88. DOI: 10.13168/AGG.2013.0056

Žigová, A., Št’astný, M. and Krejčová J.: 2008, Soil development on spongilitic marlestones in natural and human impacted systems at selected localities of Prague (Czech Republic). In: Blum, W.E.H., Gerzabek, M.H. and Vodrazka, M. (Eds.). Book of Abstracts, EUROSOIL 2008, Soil-SocietyEnvironment. Vienna, Austria, 178-179. 